\title{
Preserving Ecosystem Services on Indigenous Territory through Restoration and Management of a Cultural Keystone Species
}

\author{
Yadav Uprety ${ }^{1,+}$, Hugo Asselin ${ }^{1, *}$ and Yves Bergeron ${ }^{2}$ \\ 1 Chaire de recherche du Canada en foresterie autochtone, Université du Québec en Abitibi-Témiscamingue, \\ 445 boulevard de l'Université, Rouyn-Noranda, QC J9X 5E4, Canada; yadavuprety@gmail.com \\ 2 Chaire Industrielle CRSNG-UQAT-UQÀM en aménagement forestier durable, Institut de recherche sur les \\ forêts, Université du Québec en Abitibi-Témiscamingue, 445 boulevard de l'Université, Rouyn-Noranda, \\ QC J9X 5E4, Canada; Yves.Bergeron@uqat.ca \\ * Correspondence: hugo.asselin@uqat.ca; Tel.: +1-819-762-0971 (ext. 2621) \\ + Current address: Research Centre for Applied Science and Technology (RECAST), Tribhuvan University, \\ Kathmandu, Nepal.
}

Academic Editor: Ir. Kris verheyen

Received: 10 April 2017; Accepted: 29 May 2017; Published: 3 June 2017

\begin{abstract}
Eastern white pine (Pinus strobus L.) is a cultural keystone tree species in the forests of eastern North America, providing numerous ecosystem services to Indigenous people. White pine abundance in the landscape has considerably decreased over the last few centuries due to overharvesting, suppression of surface fires, extensive management, and plantation failure. The Kitcisakik Algonquin community of western Quebec is calling for restoration and sustainable management of white pine on its ancestral territory, to ensure provision of associated ecosystem services. We present five white pine restoration and management scenarios taking into account community needs and ecological types: (1) natural regeneration of scattered white pines to produce individuals of different sizes and ages used as medicinal plants; (2) protection of supercanopy white pines used as landmarks and for providing habitat for flagship wildlife species, and younger individuals left as regeneration and future canopy trees; (3) the uniform shelterwood system to create white pine-dominated stands that provide habitat for flagship wildlife species and support cultural activities; (4) under-canopy plantations to yield mature white pine stands for timber production; (5) mixed plantations to produce forests with aesthetic qualities that provide wildlife habitat and protect biodiversity.
\end{abstract}

Keywords: Aboriginal people; ecological restoration; ecosystem services; Pinus strobus L.; shelterwood; sustainable forest management; traditional ecological knowledge; white pine

\section{Introduction}

Eastern white pine (Pinus strobus L.) is a highly valuable tree species providing several ecosystem services, notably to Indigenous people [1-3]. Once an important component of northeastern North American forests, white pine has greatly decreased in abundance over the last few centuries due to overharvesting, fire suppression, and other factors [4-7]. Marked reduction in white pine abundance, coupled with the rising demand for high-quality timber and its many ecological, social, and cultural values [8], has increased interest in the restoration and sustainable management of white pine in a variety of ecosystems. However, white pine restoration and management are challenging for many reasons: specific site requirements for regeneration, slow initial growth rate, susceptibility to damage from white pine blister rust (Cronartium ribicola J.C. Fisch.) and white pine weevil (Pissodes strobi Peck), 
heavy browsing by herbivores, and suppression of surface fires that naturally created safe sites for seedling germination and establishment [9-12].

Indigenous people possess in-depth knowledge of ecosystem functioning that should be integrated into forest restoration and management strategies in order to fulfill cultural needs [13-15]. Moreover, industrial forest operations on public lands prioritize timber production, thus threatening Indigenous people's cultural values and access to ecosystem services on their ancestral territory. For example, white pine is a cultural keystone species for the Kitcisakik Algonquin community of western Quebec, Canada [3]. The community is concerned by the reduced abundance of white pine on its ancestral territory and has been calling for a restoration and sustainable management strategy to increase the provision of ecosystem services associated to this species. In this paper, we took into account both the cultural setting [3] and ecological constraints [16] to develop five culturally and ecologically-sound white pine restoration and management scenarios for the Kitcisakik ancestral territory. Implementing these scenarios would only have a marginal effect on the economic return of forestry operations compared to current operations, while favoring increased provision of several ecosystem services for Indigenous people, including medicinal plants, timber, cultural sites, landmarks, wildlife habitats, aesthetic value, and biodiversity. This integrated approach contributes to a growing body of literature on the inclusion of sociocultural factors in forest management and planning (e.g., [6,17-23]). It will thus be of interest to researchers and forest managers working in a variety of ecological and cultural contexts.

\section{Materials and Methods}

\subsection{Study Area}

The study area is the Kitcisakik ancestral territory (ca. $5000 \mathrm{~km}^{2}$ ) located within the boundaries of the La Vérendrye Wildlife Reserve in western Quebec, less than $300 \mathrm{~km}$ north of Ottawa (Figure 1). This area corresponds to white pine's northern limit of continuous distribution in the balsam fir (Abies balsamea (L.) Miller)-yellow birch (Betula alleghaniensis Britton.) bioclimatic domain [24]. The species reaches its absolute northern distribution limit in western Quebec ca. $150 \mathrm{~km}$ to the north-west, in the Lake Duparquet and Lake Abitibi regions where only small, scattered stands and individual trees are present $[25,26]$.

The average annual temperature in the study area is $1.2-3.3^{\circ} \mathrm{C}$, and average precipitation is 914-1014 mm/year, with 22-33\% falling as snow (Val-d'Or and Mont-Laurier weather stations, Environment Canada: http:/ / www.climate.weatheroffice.gc.ca/climate_normals). Mixed forest types are dominant, with balsam fir and yellow birch mostly accompanied by sugar maple (Acer saccharum Marsh.), red maple (Acer rubrum L.), trembling aspen (Populus tremuloides Michx.), paper birch (Betula papyrifera Marsh.), black spruce (Picea mariana (Mill.) BSP.), white spruce (Picea glauca (Moench) Voss), red pine (Pinus resinosa Ait.), jack pine (Pinus banksiana Lamb.), and white pine. 


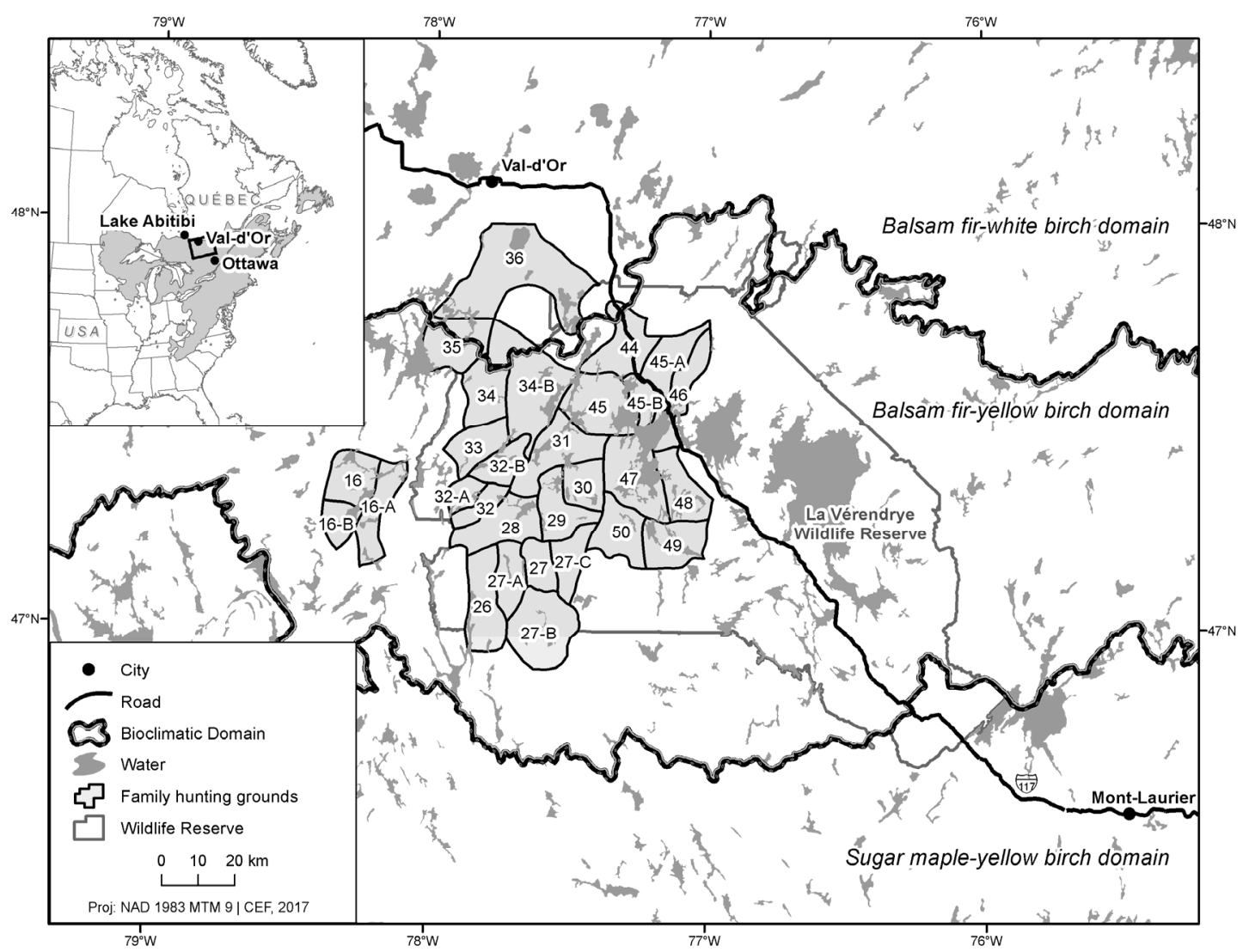

Figure 1. Location of the Kitcisakik ancestral territory in western Quebec. The inset shows the distribution of white pine in North America (after [27]).

Preindustrial forest dynamics were shaped by several disturbance factors including wildfire, spruce budworm outbreaks (Choristoneura fumiferana (Clem.)), windthrow [28], and selective logging [29]. Blister rust was introduced to North America in the beginning of the 20th century and extensive weevil damage was also first reported in the early 20th century, although the pest was first described in 1817. Crown fire was the main stand replacing disturbance controlling the landscape age structure in the preindustrial forests (fire cycle estimated at 257 years) [30]. The fire cycle of the industrial period has been estimated at more than 2000 years [30], and logging has replaced fire as the main disturbance in the study area.

\subsection{The Kitcisakik Community}

The Kitcisakik Algonquin community has ca. 480 members. Until the late 20th century, they maintained a lifestyle based on hunting, trapping, fishing, and gathering that was strongly dependent on the forest. Subsistence activities are still playing a key role in the community [31]. Young and old white pine trees and stands provide several ecosystem services to the Kitcisakik people and are a prominent part of cultural landscapes [3]. The Kitcisakik ancestral territory is on public land. Forest management is planned by the government (Ministry of Forests, Wildlife and Parks) and executed by licensed forestry companies. More than $60 \%$ of the productive forests on the Kitcisakik territory have been clear-cut over the last 40 years, following several decades of selective logging for large-diameter hardwoods and pines (white and red) [31]. Although the community is consulted during forest management planning, recurring requests for the implementation of restoration and management measures to increase white pine abundance have remained unaddressed. 


\subsection{Developing White Pine Restoration and Management Scenarios}

This study was conducted in three phases. In the first phase, we compiled information obtained from two previous studies that investigated the cultural importance and traditional ecological knowledge related to white pine [3] and white pine natural regeneration dynamics [16] on this landscape. In the second phase, we reviewed the literature on white pine management within the northern portion of its natural range. In the third phase, we identified appropriate ecological types by their suitability for white pine restoration and management and developed culturally and ecologically-sound scenarios for the Kitcisakik territory. Forest inventory data have been used in Quebec since the 1980s to produce field guides to help foresters identify forest communities and ecological types [32]. The ecological type brings together all the cover types observed under similar environmental conditions (e.g., surficial deposit, drainage), linked among themselves by elements of forest dynamics [33] (Table A1). We briefly review the results of phases 1 and 2 (Sections 3.1-3.3) and then apply these findings as they relate to phase 3 (Sections 3.4 and 3.5).

\section{Results and Discussion}

\subsection{Cultural Importance of White Pine to the Kitcisakik Algonquin}

The ecosystem services that the Kitcisakik Algonquin derive from white pine [3] depend on the characteristics of trees or stands with which they are associated: (1) medicinal uses require scattered white pine individuals of different ages distributed evenly among the matrix of family hunting grounds; (2) geographic orientation on the land is facilitated by scattered supercanopy white pines that serve as landmarks, and which are also key habitat elements for some flagship wildlife species (e.g., bald eagle (Haliaeetus leucocephalus L.); black bear (Ursus americanus Pal.)); (3) cultural and spiritual activities (e.g., knowledge transmission, reconnection with oneself to overcome difficult times) are preferably held in pure white pine or white-pine dominated stands of natural origin, which are also key habitat for other flagship wildlife species (e.g., moose (Alces americanus Clin.); American marten (Martes americana Tur.); fisher (Pekania penanti Erxl.); wolverine (Gulo gulo L.)); (4) timber production, to be economically viable, requires a minimum volume per hectare which requires pure or white pine-dominated stands originating from natural regeneration or plantations; and (5) biodiversity protection requires mixed stands where white pine is a secondary or tertiary component, which are also valued aesthetically. Different management scenarios need to be developed to perpetuate these five sets of conditions to ensure sustained provision of ecosystem services by white pine.

\subsection{Ecology of White Pine at Its Northern Limit of Continuous Distribution}

In the study area, most white pine stands belong to mature age classes $(70,90$, and $>120$ years) whereas younger stand age classes are scarce (regeneration, 30 and 50 years) [34]. White pine primarily occurs as scattered individuals in mixture with other tree species, typically black spruce, balsam fir, red maple, aspen, paper birch, and red pine. Natural white pine regeneration does occur in these stands, but in low amounts compared to the central part of the species' range [35]. Within this bioclimatic domain, recruitment success is strongly influenced by competitive or inhibitory effects of mature balsam fir, and moist substrates have a slightly positive effect on white pine regeneration [16].

Vegetative competition, blister rust, weevil, browsing (e.g., by snowshoe hare [Lepus americanus Erxl.], moose, or white-tailed deer [Odocoileus virginianus Zimm.]), seed predation by squirrels (Tamiasciurus hudsonicus Erxl.), and windthrow are potential damaging agents that can limit white pine establishment, growth, and survival. However, previous work indicated that these problems are less important in the study area than further south in the central part of white pine's range [16]. Blister rust and weevil damage only occurred in open areas (consistent with [36]) and were absent under partial to full canopy conditions producing moderate to deep shade. Blister rust could be problematic in hydric sites because of higher abundance of Ribes spp. (currant and gooseberries) that serve as alternative hosts for this pathogen [36,37]. Damage due to the white pine cone beetle (Conophthorus coniperda 
(Schwarz)) and Armillaria root disease were also reported in the Lake States [38-41], but not in the study area.

Competition with white pine regeneration by neighboring vegetation is more severe on nutrient rich, open sites [8,42,43], but the presence of an overstory canopy on such sites reduces understory light and the abundance of this competition [16]. Low browsing in the study area (reported in only $13 \%$ of the stands sampled by [16]) could mean that herbivore populations were low, or that preferred alternative food sources were available [44,45]. Seed predation was reported in $45 \%$ of the stands [16], but is probably not an important damaging agent, as mast seed years compensate for seed predation and minimize its influence on the potential for natural regeneration $[35,46,47]$.

\subsection{White Pine Restoration and Management Options}

Natural regeneration and plantations can be used for white pine management and restoration. In either case, these efforts can benefit from: (1) proper site selection and planning; (2) knowledge of the local environment, including climate, soils, topography, vegetation, and animal populations; and (3) timely and application of appropriate silvicultural interventions [41].

\subsubsection{Site Selection}

Restoration efforts should focus on stands or sites known to have previously supported white pine $[3,14]$. In the absence of precise information regarding preindustrial distribution of white pine in the study area, an alternative strategy for site selection is to focus on ecological types where white pine is currently found. Ecological types are an ecological classification of the potential vegetation based on site conditions. Current presence of white pine in stands corresponding to a particular ecological type is an indication of this ecological type's suitability as a habitat for white pine. Although nutrient-rich, mesic sites have the greatest potential for white pine regeneration, these sites present a higher risk from competing vegetation and Ribes occurrence $[41,48]$. Therefore, dry to mesic sites and sites having poor to medium nutrient content have previously been suggested for white pine restoration $[43,49]$.

More open canopies promote vegetation competition, and blister rust and weevil damage. Therefore, the best silvicultural practice is to manage white pine under an existing overstory [36,50,51]. Well-drained and well-aerated south-facing sites should be preferred. Such more open sites favor rapid evaporation of morning dew creating unsuitable conditions for blister rust. Small canopy openings are more susceptible to blister rust, as they retain moisture [52-54]. Hence, topographic conditions and locations that favor persistent dew formation during cool, windless nights should be avoided [55]. Hollows or damp depressions should thus be avoided, as well as lower slopes, especially those with a northern exposure, small valleys or small openings surrounded by mature stands, and sites with dense vegetation where Ribes form large colonies [55]. A high abundance of broadleaf forbs, grasses, ferns, shrubs, and other woody vegetation typically develops rapidly after harvest disturbance where site preparation is not applied. Dense understory vegetation layers are known to limit air circulation and trap cool night air, thereby promoting high relative humidity and increased dew formation [56].

Intermediate understory light conditions (33-65\%) had low amounts of blister rust and weevil damage in the study area, while allowing adequate stocking of white pine regeneration [16]. Near $50 \%$ light condition is an oft-suggested level for keeping balance between protection against pests and adequate growth [51,57-60]. Short-term volume losses of white pine grown under shaded conditions are compensated by long-term gain, as white pine grows taller and larger over time than other tree species present in the study area.

Although Ribes spp. can threaten restoration success, their abundance within a stand is not always correlated with local rust damage because the spores can be dispersed over long distances [61]. Past efforts to control Ribes mostly focused on eradication but were difficult, costly, and ineffective [37]. However, removal of Ribes from plantation sites and their close proximity could reduce the hazard [62]. New tactics emphasize biocides, biological agents, and use of silviculture to reduce Ribes regeneration [40]. Such methods are costly and are typically used only in high-value plantations aimed at timber production. 


\subsubsection{Site Preparation}

Site preparation is used to enhance pine regeneration, creating a favorable seedbed by clearing competitive vegetation and exposing the mineral soil [41]. This was historically done by recurrent surface fires that have mostly been eliminated by fire suppression policies in several jurisdictions including Quebec. Site preparation can be done mechanically, with chemicals or prescribed burning (e.g., [51]), the latter two methods being prohibited in Quebec (but see [63] for a thorough discussion of the acceptability of such practices in Indigenous contexts). If natural regeneration is the selected strategy for white pine establishment, site preparation must coincide with the occurrence of mast seed years to maximize stocking.

\subsubsection{Shelterwood System for White Pine Management}

The uniform shelterwood system is an effective management tool for regenerating white pine in pine-dominated stands where adequate seed trees are present $[12,50,64]$. This silvicultural system emulates the surface fires that historically favored white pine regeneration by clearing the understory and some of the canopy trees, while retaining part of the canopy, including seed-producing canopy trees $[65,66]$. Residual canopy trees provide seeds for regeneration, as well as overstory protection to favor white pine establishment [59]. In this system, partial harvests (two to four passes) are done prior to final or near-complete overstory removal, depending on stand age [12,43,50,59] (Table 1).

Table 1. Step-by-step description of the uniform shelterwood system for white pine regeneration (after [59]).

\begin{tabular}{cl}
\hline \multicolumn{1}{c}{ Steps } & \multicolumn{1}{c}{ Implications } \\
\hline Preparatory cut & $\begin{array}{l}\text { Is used to improve the vigor of prospective seed-bearing trees. Low vigor trees are harvested while } \\
\text { larger, healthy trees are retained. }\end{array}$ \\
\hline Regeneration cut & $\begin{array}{l}\text { Retains the largest, healthiest trees in the stand to be seed sources and to create conditions favorable } \\
\text { for white pine establishment, survival, and growth, and limiting to blister rust and weevil damage. } \\
\text { Additional trees are kept for wildlife habitat such as live cavity, mast, and supercanopy trees. }\end{array}$ \\
\hline First removal cut & $\begin{array}{l}\text { Applied to stands that have sufficient regeneration (at least 30 cm in height) in the understory to form } \\
\text { a new white pine stand in the future. Some of the residual trees are harvested mimicking the eventual } \\
\text { death of some trees after a natural disturbance such as a fire. Stands may be opened so that 50\% } \\
\text { crown closure remains after this cut. This creates conditions that reduce blister rust and weevil } \\
\text { damage in white pine seedlings. }\end{array}$ \\
\hline Final removal cut & $\begin{array}{l}\text { Applied when white pine regeneration is about } 3 \text { m in height. Some parent trees (usually 10-20 per ha) } \\
\text { are retained for ecological (e.g., veterans) and habitat (e.g., mast, supercanopy, and cavity trees) value. }\end{array}$ \\
\hline
\end{tabular}

Stands with a white pine basal area greater than $12 \mathrm{~m}^{2} /$ ha and a low component of red pine, spruce, or hardwood species can be managed under the shelterwood system [51]. The selection of seed trees should be based on the following criteria: trees in the dominant or co-dominant crown class; disease-free with clear, straight boles; well-formed crowns, with fine branching; and signs of good growth as evidenced by small, tight bark-flakes and good coverage of foliage on branches [50].

Assuming that a regeneration cut is properly timed to coincide with a mast year (for white pine, good seed crops occur every 3 to 10 years in the northern part of its range [27,35]), sites should be prepared using mechanical scarification to create suitable seedbed conditions. Where mast seed years do not coincide with site preparation, underplanting of white pine nursery stock will be needed to ensure the desired initial stocking is attained.

\subsubsection{Underplanting White Pine}

Underplanting white pine in hardwood, mixedwood, or conifer stands provides moderate shade needed to reduce blister rust and weevil damage with little growth loss. However, heavy shading can reduce growth, vigor, and survival of white pine [58]. The stands should thus be thinned initially if canopy is too dense to create adequate light for survival and competitive growth of underplanted pine. 
Some form of canopy needs to be retained until pines are $>5 \mathrm{~m}$ tall for protection against weevil [12]. Underplanting in balsam fir stands should be avoided, as balsam fir shows inhibitory effects on white pine regeneration [16]. In aspen stands, the thinning level should be low, as the species can produce vigorous root suckers after logging [67]. Underplanting following strip cutting in deciduous stands (e.g., birch, aspen, maple, but also eastern larch [Larix laricina (Du Roi) K. Koch]) can be problematic, as such sites are warmer and drier in the spring, prior to leaf growth, and are thus more prone to weevil attack at the time when adult insects are more active [68].

\subsubsection{Mixed Plantations}

Mixed plantations (i.e., planting more than one species, or planting one species into an area with natural regeneration of other species) could be an option in open or partial canopy conditions and are the preferred restoration option of the Kitcisakik community [3] because they favor biodiversity [69]. The species to be planted and their proportion relative to white pine should be decided carefully. Mixedwood (conifer + hardwood) plantations are recommended, keeping the white pine proportion low (i.e., <33\%). White pine can compete with thin-crowned species such as paper birch, but not with aspen or maple [70]. In a mixed Norway spruce (Picea abies (L.) H. Kars.)-white pine plantation trial (one-third white pine), weevil preferentially attacked Norway spruce [55]. Interestingly, weevil attacks did not severely affect spruce wood quality [55], hence maintaining good potential from a forestry perspective. Furthermore, in such plantations, commercially valuable spruce can be harvested during the first thinning operation [55].

\subsubsection{Pure White Pine Plantations}

Planting white pine in a clearcut or in an open field requires weighing the potential for greater tree growth against the threat of increased blister rust and weevil damage [41]. Pure white pine plantations in open conditions will require more intensive silviculture than in shelterwood, underplantating, or mixed plantations. An important practice in pure plantations is to maintain high densities (i.e., 2000-3000 stems/ha) until trees reach about $6 \mathrm{~m}$ in height [36]. This practice greatly improves white pine stem wood quality and growth [51]. Moreover, higher density creates competition and forces rapid height growth with minimal terminal diameter growth unfavorable to weevil. In addition, high density causes natural mortality of lower branches, which favors rust control [36]. Retaining more white pine trees at the time of pre-commercial thinning and also at harvest could compensate for later blister rust mortality and increase the likelihood of maintaining resistant trees on site [71].

Restoration in high quality sites that are usually prone to vegetation competition requires application of silvicultural techniques to promote regeneration establishment and growth [72]. Restoration efforts on clearcut sites should also focus on early management of understory vegetation and the gradual reduction of overtopping cover from woody vegetation [8,73]. As white pine grows relatively slow for the first five years, early control of competing vegetation is critical $[43,59]$. Competing vegetation control favors white pine seedling growth by increasing resource availability, while decreasing the risk of blister rust attack by altering the microclimate. Thinning can also be done to remove competition from overtopping aspen and birch [10]. Planting of large nursery stock $(\sim 50 \mathrm{~cm})$ could be an option to increase the competitive potential of white pine.

Most fatal blister rust cankers occur in the lower portions of the trees, saplings, and seedlings, thus repeated pruning of lower branches can considerably reduce the likelihood of lethal cankers $[36,53,74]$. If the rate of infection is above $8 \%$ when the trees reach their sixth year, systematic pruning of lower branches is recommended [75]. According to [76], pruning should be performed yearly until trees reach $4.9 \mathrm{~m}$ height. Furthermore, pruning $2.7-5.2 \mathrm{~m}$ of the lower stem and maintaining $66 \%$ of the live crown of small white pine trees reduces the likelihood of lethal infection [41].

Although browsing impact is not important in our study area [16], damage severity could change with animal population cycles, availability of alternative food sources, or height of the surrounding vegetation $[9,45,77]$. Furthermore, while hunting controls herbivore populations in the study area, 
high population levels in other jurisdictions can inhibit pine regeneration. Browsing of terminal shoots and branches causes forked stems, growth loss, and seedling mortality, consequently delaying canopy recruitment, and decreasing wood quality [12,44,51].

\subsection{White Pine Restoration and Management Scenarios}

We propose five restoration and management scenarios to increase or maintain the provision of each of the five categories of ecosystem services provided by white pine, based on site conditions and white pine autecology (Table 2). There were a total of 179,489 productive forest stands (mapped polygons) in the study area according to the fourth decadal forest inventory of the Quebec Ministry of Forests, Wildlife and Parks, of which only 4507 (2.5\%) had white pine as first, second, or third species in dominance importance. However, the corresponding ecological types represented 168,858 stands (94\% of all stands), thus showing enormous potential for white pine restoration and management on Kitcisakik territory.

Table 2. White pine restoration and management framework for the Kitcisakik Algonquin territory.

\begin{tabular}{cccc}
\hline $\begin{array}{c}\text { Ecosystem Services } \\
\text { Categories }\end{array}$ & $\begin{array}{c}\text { White Pine } \\
\text { Requirements }\end{array}$ & Restoration and Management Scenario & Scenario Number \\
\hline Medicinal uses & $\begin{array}{c}\text { Scattered young and } \\
\text { mature trees }\end{array}$ & $\begin{array}{c}\text { Protection of current young and mature trees } \\
\text { and natural regeneration of new trees }\end{array}$ & I \\
\hline $\begin{array}{c}\text { Orientation on the land and } \\
\text { wildlife habitat }\end{array}$ & $\begin{array}{c}\text { Scattered supercanopy } \\
\text { trees }\end{array}$ & $\begin{array}{c}\text { Protection of current supercanopy trees and } \\
\text { natural regeneration of new trees }\end{array}$ & II \\
$\begin{array}{c}\text { Connection with the land } \\
\text { and wildlife habitat }\end{array}$ & $\begin{array}{c}\text { Natural white } \\
\text { pine-dominated stands }\end{array}$ & $\begin{array}{l}\text { Conservation of current natural stands and } \\
\text { natural regeneration of new stands through } \\
\text { uniform shelterwood }\end{array}$ & III \\
\hline Timber production & $\begin{array}{c}\text { Pure or white } \\
\text { pine-dominated stands }\end{array}$ & Underplanting or pure/mixed plantations & IV \\
\hline Biodiversity and aesthetics & Mixed stands & Natural regeneration or mixed plantations & V \\
\hline
\end{tabular}

To develop the restoration and management scenarios, we focused on relatively abundant ecological types (i.e., comprising $>100$ stands) for which white pine is currently found in $\geq 1 \%$ of the stands of the study area. Furthermore, we excluded ecological types with subhydric or hydric drainage, as they are susceptible to blister rust. The final list of 16 ecological types comprised 101,124 stands representing $56 \%$ of the productive forest stands (Tables 3 and A1). Following ethical best practices [78], the scenarios were discussed with-and approved by — the Kitcisakik Land Department.

Table 3. Ecological types and suggested scenarios for white pine (WP) restoration and management.

\begin{tabular}{|c|c|c|c|c|c|c|c|}
\hline \multirow{2}{*}{$\begin{array}{l}\text { Ecological } \\
\text { Types * }\end{array}$} & \multirow{2}{*}{$\begin{array}{l}\text { No. of } \\
\text { Stands }\end{array}$} & \multicolumn{3}{|c|}{ No. of Stands with WP as 1st, 2nd, or 3rd Component } & \multirow{2}{*}{$\begin{array}{l}\text { Total Stands } \\
\text { with WP }\end{array}$} & \multirow{2}{*}{$\begin{array}{l}\% \text { Stands } \\
\text { with WP }\end{array}$} & \multirow{2}{*}{ Scenarios ** } \\
\hline & & 1st & 2nd & 3rd & & & \\
\hline MJ10 & 296 & 20 & 2 & 19 & 41 & 13.85 & $\mathrm{I}, \mathrm{V}$ \\
\hline MJ12 & 13,253 & 88 & 45 & 246 & 379 & 2.85 & I, II, V \\
\hline MJ20 & 1500 & 22 & 24 & 16 & 62 & 4.13 & $\mathrm{I}, \mathrm{V}$ \\
\hline MJ21 & 4459 & 58 & 47 & 131 & 236 & 5.19 & I, II, V \\
\hline MJ22 & 39,958 & 547 & 265 & 718 & 1530 & 3.82 & I, II, V \\
\hline MS21 & 4856 & 83 & 35 & 121 & 239 & 4.92 & I, II, V \\
\hline MS22 & 5490 & 21 & 22 & 19 & 62 & 1.13 & II, V \\
\hline RP10 & 222 & 100 & 61 & 4 & 165 & 74.32 & III \\
\hline RP11 & 273 & 149 & 48 & 11 & 208 & 76.19 & III \\
\hline RP12 & 406 & 251 & 61 & 19 & 331 & 81.52 & III \\
\hline RS10 & 226 & 5 & 21 & 0 & 26 & 11.50 & I, IV, V \\
\hline RS11 & 302 & 1 & 22 & 0 & 23 & 7.61 & I, II, IV, V \\
\hline RS12 & 2901 & 22 & 124 & 0 & 146 & 5.03 & II, IV \\
\hline RS20 & 5520 & 9 & 85 & 0 & 94 & 1.70 & I, IV, V \\
\hline RS21 & 9086 & 107 & 102 & 5 & 214 & 2.35 & I, II, IV, V \\
\hline RS22 & 12,376 & 49 & 196 & 0 & 245 & 1.97 & II, IV \\
\hline
\end{tabular}

* See Table A1 for definition of ecological types. ** See Table 2. 


\subsubsection{Scenario I: Scattered White Pine Individuals of All Ages}

People from Kitcisakik use naturally-grown young, mature, and old white pine trees for medicinal purposes [3]. Ecological types that support white pine as a minor component could be targeted for this scenario (Table 3), as only scattered pines are needed. Hence, all that is needed is to protect current white pines and to make sure natural regeneration occurs and is let free to grow. Minimal silvicultural intervention is required. Because mature and old trees have special medicinal properties after having been struck by lightning [3], a special attention should be given to retaining such trees.

\subsubsection{Scenario II: Scattered Supercanopy White Pines}

Scattered supercanopy white pine trees provide landmarks and are a key habitat element for flagship species such as bald eagle and black bear. Therefore, in addition to protecting current supercanopy trees, naturally regenerated white pine seedlings or saplings should be protected and left to grow so that future landmark trees will be present on all family hunting grounds. As for scenario I, minimal silvicultural intervention is required. Ecological types that support white pine as a minor component could be targeted.

\subsubsection{Scenario III: Mature, White Pine-Dominated Stands of Natural Origin}

Mature white pine dominated stands are important for cultural activities and wildlife habitat and should be actively managed for natural regeneration, as plantations are less favorable for wildlife [79], and are negatively perceived by Indigenous people [80].

The uniform shelterwood system could be used to maintain the presence of white pine-dominated stands on the landscape. Three of the 16 selected ecological types are dominated by white and red pines, and white pine is currently present in $74-82 \%$ of these ecological types (Table 3). As these ecological types are spread evenly on the territory, they provide an opportunity to maintain white pine-dominated stands in all family hunting grounds, as well as near settlements, thus providing equal access to ecosystem services among Indigenous families [15,81].

\subsubsection{Scenario IV: Pure or White Pine-Dominated Stands from Plantations}

Pure or white pine-dominated stands are required for timber production. These can be obtained/maintained using either of two approaches depending on ecological type. One approach is to keep some of the canopy and underplant pine, while the other is to clearcut and plant pine. Undercanopy white pine plantations can be applied in ecological types with spruce (Picea spp.), or eastern white cedar (Thuja occidentalis L.) as major components (Table 3). Both approaches will achieve the same objective of timber production.

\subsubsection{Scenario V: Mixed Stands where White Pine is a Secondary or Tertiary Component}

Mixed stands are valued for aesthetic purposes, as habitat for wildlife, and for their potential to preserve biodiversity. Mixed plantations can be established in all ecological types that support white pine where timber production through plantation establishment is not an attractive option given site characteristics.

\subsection{Spatial Distribution of the Scenarios}

Ecological types supporting all scenarios are fairly evenly distributed among family hunting grounds, thus meeting a request by the Kitcisakik people that benefits and disadvantages of forest management should be equitably distributed [82]. Ecological types supporting scenarios I and II are relatively abundant and represent $44 \%$ and $52 \%$, respectively, of productive forest stands on Kitcisakik territory. Preservation of scattered individuals (for medicinal uses or as supercanopy landmark trees) should thus not be problematic and would likely have minimal impact on the profitability of forest management operations, as they do not require silvicultural interventions. Scenario V (mixed 
plantations) would be possible on $47 \%$ of productive forest stands. While this shows interesting potential, it could nevertheless prove difficult to implement, as the Quebec forest industry favors pure plantations. Scenarios III and IV would require more intensive and more frequent silvicultural interventions and should thus be preferentially realized near the settlement, where opportunities currently exist, but only in a very limited number of stands. Scenario III is currently limited to less than $1 \%$ of productive stands, underlining the importance of protecting the remaining natural white pine stands and of facilitating the regeneration of new ones. About $17 \%$ of productive stands are suitable for scenario IV, providing opportunity for restoration and management of white pine stands for timber production. Options for white pine restoration and management are more limited in the northern and eastern parts of Kitcisakik territory, where balsam fir stands are abundant and where suitable ecological types are less frequent (Figure 2).
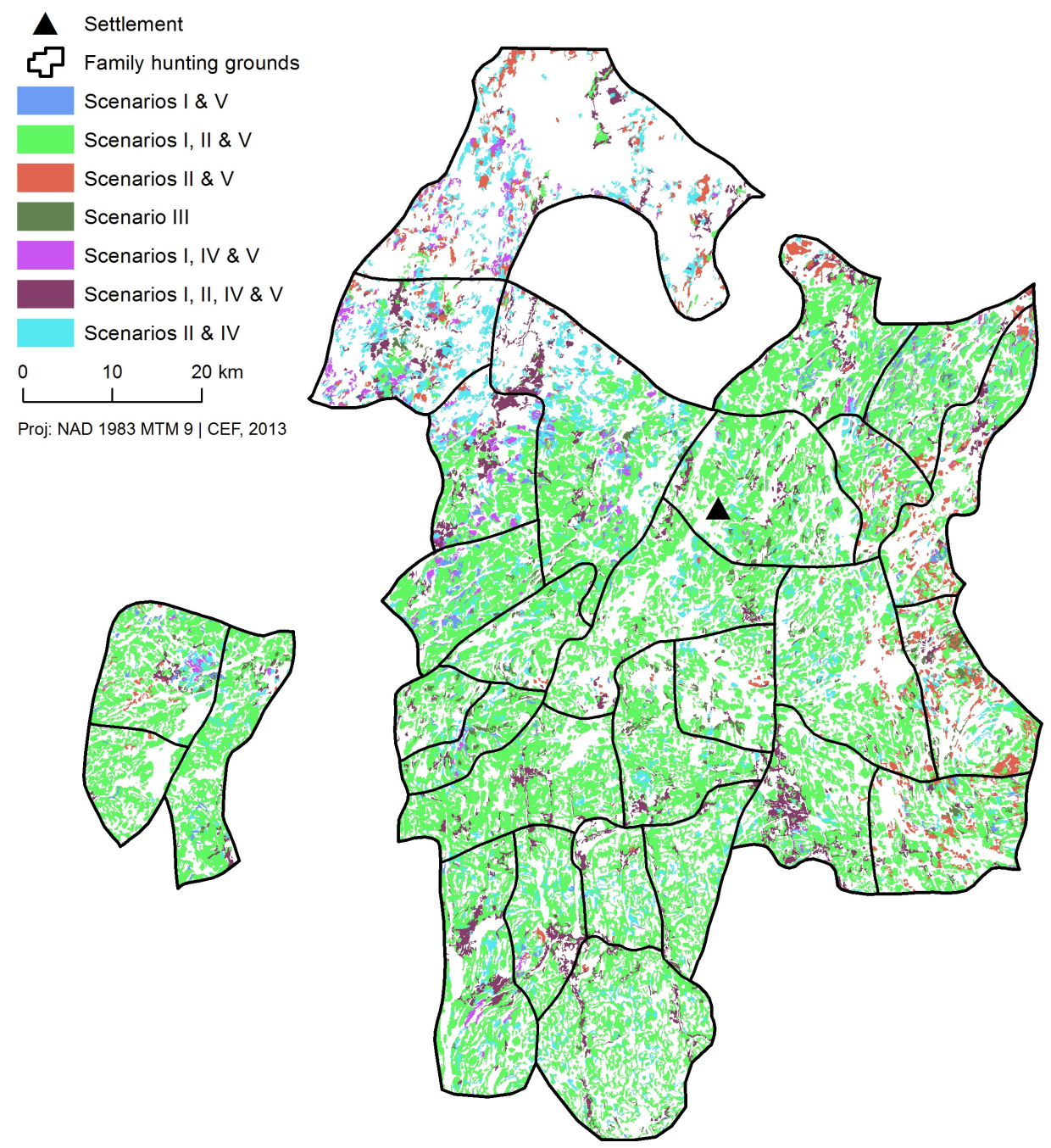

Figure 2. Spatial distribution of the ecological types supporting white pine restoration and management scenarios on Kitcisakik territory. See Figure 1 for details on the location of the territory, and Table 2 for details about the scenarios.

\section{Conclusions}

This paper addressed a request from the Kitcisakik Algonquin community to develop management recommendations for white pine on their ancestral territory. The aim is not to actively manage for white pine dominated stands everywhere on the territory for industrial purposes, but rather to maintain or increase the provision of white pine-associated ecosystem services to the Kitcisakik 
community. The five proposed scenarios would have low impact on profitability of the forest industry, as they require minimal silvicultural intervention (I and II), or would take place on a very small portion of the total productive forest stands (III, IV, and V). Moreover, the proposed scenarios correspond to the philosophy behind ecosystem-based forest management [83-85], as the shelterwood system emulates surface fires and scattered white pines in the landscape are maintained by small-scale canopy gaps. Ecosystem-based forest management has been favored on public lands of Quebec since 2010. Pure plantations, in this context, could not be considered to be emulating natural processes, but could be justified at a small scale and near settlements to favor wood production. Scenarios III and IV could be labor intensive and costly. However, if done at a small scale in a cultural context, people from Kitcisakik could contribute to site selection, preparation, management, and monitoring [14]. The responsibility of some of the restoration and management operations on family hunting grounds could be given to community members once guidelines and training are provided. Such community-based approaches have been shown to be efficient, to have increased legitimacy, and to be more sustainable [86].

Indigenous peoples' participation, and recognition and inclusion of their knowledge into restoration and management projects can contribute to building a strong partnership for successful implementation that significantly improves social acceptability, economic feasibility, and ecological viability of restoration projects $[14,87,88]$. Therefore, a shift from "just another stakeholder" to "shared decision makers" [89] is possible. The approach presented here, where restoration and management scenarios take into account cultural needs and ecological constraints, could find wide application in diverse forest settings, as it could help meet the objectives of certification standards (e.g., Forest Stewardship Council-FSC) with regards to the rights and needs of Indigenous people.

Acknowledgments: Thanks to Mélanie Desrochers (Center for Forest Studies, Université du Québec à Montréal) for helping with Figure 1. The Chaire Desjardins en développement des petites collectivités, the Réseau de recherche et de connaissances relatives aux peuples autochtones (DIALOG), and the Centre de recherche sur la gouvernance des ressources naturelles et du territoire (CRGRNT) provided financial support for this project through scholarships to Y.U.

Author Contributions: Y.U., H.A., and Y.B. conceived and designed the experiments; Y.U. performed the experiments and analyzed the data; Y.U., H.A., and Y.B. wrote the paper.

Conflicts of Interest: The authors declare no conflict of interest. The founding sponsors had no role in the design of the study; in the collection, analyses, or interpretation of data; in the writing of the manuscript, and in the decision to publish the results.

\section{Appendix A}

Table A1. Signification of inventory codes for ecological types, following the classification of the Quebec Ministry of Forests, Wildlife and Parks.

\begin{tabular}{ll}
\hline Code & \\
\hline MJ10 & Yellow birch, balsam fir, sugar maple on very thin deposits of varied texture with a xeric to hydric drainage \\
MJ12 & Yellow birch, balsam fir, sugar maple on thin to thick medium deposits with a mesic drainage \\
MJ20 & Yellow birch, balsam fir on very thin deposits of varied texture with a xeric to hydric drainage \\
MJ21 & Yellow birch, balsam fir on thin to thick coarse deposits with a xeric to mesic drainage \\
MJ22 & Yellow birch, balsam fir on thin to thick medium deposits with a mesic drainage \\
MS21 & Balsam fir, paper birch on thin to thick coarse deposits with a xeric to mesic drainage \\
MS22 & Balsam fir, paper birch on thin to thick medium deposits with a mesic drainage \\
RP10 & White or red pine on very thin deposits of varied texture with a xeric to hydric drainage \\
RP11 & White or red pine on thin to thick coarse deposits with a xeric to mesic drainage \\
RP12 & White or red pine on thin to thick medium deposits with a mesic drainage \\
RS10 & Balsam fir, eastern white cedar, on very thin deposits of varied texture with a xeric to hydric drainage \\
RS11 & Balsam fir, eastern white cedar, on thin to thick coarse deposits with a xeric to mesic drainage \\
RS12 & Balsam fir, eastern white cedar, on thin to thick medium deposits with a mesic drainage \\
RS20 & Balsam fir, black spruce on very thin deposits of varied texture with a xeric to hydric drainage \\
RS21 & Balsam fir, black spruce on thin to thick coarse deposits with a xeric to mesic drainage \\
RS22 & Balsam fir, black spruce on thin to thick medium deposits with a mesic drainage \\
\hline
\end{tabular}




\section{References}

1. Rogers, L.L.; Lindquist, E.L. Supercanopy white pine and wildlife. In Proceedings of the White Pine Symposium: History, Ecology, Policy and Management, Duluth, MN, USA, 16-18 September 1992; Stine, R.A., Baughman, M.J., Eds.; Department of Forestry Resources, University of Minnesota: St. Paul, MN, USA, 1992.; pp. 39-43.

2. Schroeder, H.W. The tree of peace: symbolic and spiritual values of the white pine. In Proceedings of the White Pine Symposium: History, Ecology, Policy and Management, Duluth, MN, USA, 16-18 September 1992; Stine, R.A., Baughman, M.J., Eds.; Department of Forestry Resources, University of Minnesota: St. Paul, MN, USA, 1992.; pp. 73-83.

3. Uprety, Y.; Asselin, H.; Bergeron, Y. Cultural importance of white pine (Pinus strobus L.) to the Kitcisakik Algonquin community of western Quebec, Canada. Can. J. For. Res. 2013, 43, 544-551. [CrossRef]

4. Abrams, M.D. Eastern white pine versatility in the presettlement forest. BioScience 2001, 51, 967-979. [CrossRef]

5. Thompson, I.D.; Simard, J.H.; Titman, R.D. Historical changes in white pine (Pinus strobus L.) density in Algonquin Park, Ontario, during the 19th century. Nat. Areas J. 2006, 26, 61-71. [CrossRef]

6. Steen-Adams, M.M.; Mladenoff, D.J.; Langston, N.C.; Liu, F.; Zhu, J. Influence of biophysical factors and differences in Ojibwe reservation versus Euro-American social histories on forest landscape change in northern Wisconsin, USA. Landsc. Ecol. 2011, 26, 1165-1178. [CrossRef]

7. Danneyrolles, V.; Arseneault, D.; Bergeron, Y. Pre-industrial landscape composition patterns and post-industrial changes at the temperate-boreal forest interface in western Quebec, Canada. J. Veg. Sci. 2016, 27, 470-481. [CrossRef]

8. Pitt, D.G.; Morneault, A.; Parker, W.C.; Stinson, A.; Lanteigne, L. The effects of herbaceous and woody competition on planted white pine in a clearcut site. For. Ecol. Manag. 2009, 257, 1281-1291. [CrossRef]

9. Tester, J.R.; Starfield, A.M.; Frelich, L.E. Modeling for ecosystem management in Minnesota pine forest. Biol. Conserv. 1997, 80, 313-324. [CrossRef]

10. Burgess, D.; Robinson, C.; Wetzel, S. Eastern white pine response to release 30 years after partial harvesting in pine mixed wood forest. For. Ecol. Manag. 2005, 209, 117-129. [CrossRef]

11. Steen-Adams, M.M.; Langston, N.; Mladenoff, D.J. White pine in the northern forests: An ecological and management history of white pine on the Bad River Reservation of Wisconsin. Environ. Hist. 2007, 12, 614-648. [CrossRef]

12. Latremouille, C.; Parker, W.C.; McPherson, S.; Pinto, F.; Fox, B.; McKinnon, L. Ecology and Management of White Pine in the Lake Abitibi (3E) and Lake Temagami (4E) Ecoregions of Ontario; Science Development and Transfer Series No. 004; Ministry of Natural Resources: South Porcupine, ON, Canada, 2008.

13. Parrotta, J.A.; Trosper, R.L. (Eds.) Traditional Forest-Related Knowledge: Sustaining Communities, Ecosystems and Biocultural Diversity; World Forest Series vol. 12; Springer: Dordrecht, The Netherlands, 2012.

14. Uprety, Y.; Asselin, H.; Bergeron, Y.; Doyon, F.; Boucher, J.-F. Contribution of traditional knowledge to ecological restoration: Practices and applications. Ecoscience 2012, 19, 225-237. [CrossRef]

15. Asselin, H. Indigenous forest knowledge. In Routledge Handbook of Forest Ecology; Peh, K., Corlett, R., Bergeron, Y., Eds.; Routledge: New York, NY, USA, 2015; pp. 586-596.

16. Uprety, Y.; Asselin, H.; Bergeron, Y.; Mazerolle, M.J. White pine (Pinus strobus L.) regeneration dynamics at the species' northern limit of continuous distribution. New For. 2014, 45, 131-147. [CrossRef]

17. Jiao, Y.M.; Li, X.Z.; Liang, L.H.; Takeuchi, K.; Okuro, T.; Zhang, D.D.; Sun, L.F. Indigenous ecological knowledge and natural resource management in the cultural landscape of China's Hani Terraces. Ecol. Res. 2012, 27, 247-263. [CrossRef]

18. Mason, L.; White, G.; Morishima, G.; Alvarado, E.; Andrew, L.; Clark, F.; Durglo, M.; Durglo, J.; Eneas, J.; Erickson, J.; et al. Listening and learning from traditional knowledge and western science: A dialogue on contemporary challenges of forest health and wildfire. J. For. 2012, 110, 187-193. [CrossRef]

19. Emery, M.R.; Wrobel, A.; Hansen, M.H.; Dockry, M.; Moser, W.K.; Stark, K.J.; Gilbert, J.H. Using traditional ecological knowledge as a basis for targeted forest inventories: Paper birch (Betula papyrifera) in the US Great Lakes region. J. For. 2014, 112, 207-214. [CrossRef] 
20. Armatas, C.; Venn, T.; McBride, B.; Watson, A.; Carver, S. Opportunities to utilize traditional phenological knowledge to support adaptive management of social-ecological systems vulnerable to changes in climate and fire regimes. Ecol. Soc. 2016, 21. [CrossRef]

21. Tendeng, B.; Asselin, H.; Imbeau, L. Moose (Alces americanus) habitat suitability in temperate deciduous forests based on Algonquin traditional knowledge and on a habitat suitability index. Ecoscience 2016, 23, 77-87. [CrossRef]

22. Lawler, J.H.; Bullock, R.C. A case for Indigenous community forestry. J. For. 2017, 115, 117-125. [CrossRef]

23. Reo, N.J.; Whyte, K.P.; McGregor, D.; Smith, M.A.; Jenkins, J.F. Factors that support Indigenous involvement in multi-actor environmental stewardship. AlterNative 2017, 13. [CrossRef]

24. Saucier, J.-P.; Bergeron, J.-P.; Grondin, P.; Robitaille, A. Les régions écologiques du Québec méridional (troisième version). L'Aubelle 1998, 124, S1-S12.

25. Bergeron, Y.; Leduc, A.; Li, T. Explaining the distribution of Pinus spp. in a Canadian boreal insular landscape. J. Veg. Sci. 1997, 8, 37-44. [CrossRef]

26. Engelmark, O.; Bergeron, Y.; Flannigan, M.D. Age structure of eastern white pine, Pinus strobus L., at its northern distribution limit in Quebec. Can. Field Nat. 2000, 114, 601-604.

27. Wendel, G.W.; Smith, H.C. Pinus strobus L., Eastern white pine. In Silvics of North America; Agriculture Handbook 654; Conifers; Burns, R.M., Honkala, B.H., Eds.; U.S.D.A. Forest Service: Washington, DC, USA, 1990; Volume 1.

28. Boucher, Y.; Bouchard, M.; Grondin, P.; Tardif, P. Le Registre des États de Référence : Intégration des Connaissances sur la Structure, la Composition et la Dynamique des Paysages Forestiers Naturels du Québec Méridional. Mémoire de Recherche Orestière $n^{\circ}$ 161; Direction de la recherche forestière, Ministère des Ressources naturelles et de la Faune, Gouvernement du Québec: Quebec City, QC, Canada, 2011.

29. Asselin, M. L'Abitibi-Témiscamingue: Trois sous-région. In Histoire de l'Abitibi-Témiscamingue; Vincent, O., Ed.; Institut québécois de recherche sur la culture: Quebec City, QC, Canada, 1995; pp. 21-65.

30. Bergeron, Y.; Cyr, D.; Drever, C.D.; Flannigan, M.; Gauthier, S.; Kneeshaw, D.; Lauzon, È.; Leduc, A.; Le Goff, H.; Lesieur, D.; et al. Past, current, and future fire frequencies in Quebec's commercial forests: implications for the cumulative effects of harvesting and fire on age-class structure and natural disturbance-based management. Can. J. For. Res. 2006, 36, 2737-2744. [CrossRef]

31. Saint-Arnaud, M.; Asselin, H.; Dubé, C.; Croteau, Y.; Papatie, C. Developing criteria and indicators for aboriginal forestry: Mutual learning through collaborative research. In Changing the Culture of Forestry in Canada: Building Effective Institutions for Aboriginal Engagement in Sustainable Forest Management; Stevenson, M.G., Natcher, D.C., Eds.; Canadian Circumpolar Institute Press: Edmonton, AB, Canada, 2009; pp. 85-105.

32. Blouin, J.; Berger, J.-P. Guide de Reconnaissance des Types Écologiques de la Région Écologique $5 b$ Coteaux du Réservoir Gouin; Ministère des Ressources Naturelles, Forêt Québec, Direction des inventaires forestiers, Division de la classification écologique et productivité des stations: Quebec City, QC, Canada, 2001.

33. Grondin, P.; Saucier, J.-P.; Blouin, J.; Gosselin, J.; Robitaille, A. Information Écologique et Planification Forestières au Québec, Canada; Note de recherche forestière 118; Ministère des Ressources naturelles, de la Faune et des Parcs, Direction de la recherche forestière: Quebec City, QC, Canada, 2003.

34. Delisle, S. Modèle Prédictif D'occurrence du pin Blanc sur le Territoire des Anicinapek de Kitcisakik. Ph.D. Thèse, Faculté de foresterie, de géographie et de géomatique, Université Laval, Quebec City, QC, Canada, 2011.

35. Parker, W.C.; Noland, T.L. ; Morneault. A.E. Comparative mast seed production in unmanaged and shelterwood white pine (Pinus strobus L.) stands in central Ontario. New For. 2013, 44, 613-628. [CrossRef]

36. Katovich, S.; Mielke, M. How to Manage Eastern White Pine to Minimize Damage from Blister Rust and White Pine Weevil; NAFR-01-93; USDA Forest Service: Newtown Square, PA, USA, 1993.

37. Zambino, P.J. Biology and pathology of Ribes and their implications for management of white pine blister rust. For. Pathol. 2010, 40, 264-291. [CrossRef]

38. Katovich, S.A.; O'Brien, J.G.; Mielke, M.E.; Ostry, M.E. Restoration and management of eastern white pine within high blister rust hazard zones in the Lake States. In Silviculture in Special Places; Sheppard, W.D., Askew, L.G., Eds.; RMRS-P-34; USDA Forest Service: Fort Collins, CO, USA, 2004; pp. 135-145. 
39. Zenner, E.K.; Puettmann, K.J.; Krueger, J.A. Early growth responses of naturally regenerated eastern white pine (Pinus strobus L.) to partial release from juvenile aspen and pathological pruning. North J. Appl. For. 2005, 22, 27-34.

40. Hunt, R.S.; Geils, B.W.; Hummer, K.E. White pines, Ribes, and blister rust: Integration and action. For. Pathol. 2010, 40, 402-417. [CrossRef]

41. Ostry, M.E.; Laflamme, G.; Katovich, S.A. Silvicultural approaches for management of eastern white pine to minimize impacts of damaging agents. For. Pathol. 2010, 40, 332-340. [CrossRef]

42. Gillespie, A.R.; Hocker, H.W. The influence of competition on individual white pine thinning response. Can. J. For. Res. 1986, 16, 1355-1359. [CrossRef]

43. Burgess, D.; Wetzel, S. Nutrient availability and regeneration response after partial cutting and site preparation in eastern white pine. For. Ecol. Manag. 2000, 138, 249-262. [CrossRef]

44. Pastor, J. Browsing damage to white pine. In Proceedings of the White Pine Symposium: History, Ecology, Policy and Management, Duluth, MN, USA, 16-18 September 1992; Stine, R.A., Baughman, M.J., Eds.; Department of Forestry Resources, University of Minnesota: St. Paul, MN, USA, 1992.; pp. 137-144.

45. Saunders, M.R.; Puettmann, K.J. Use of vegetational characteristics and browsing patterns to predict deer damage in eastern white pine (Pinus strobus) plantations. North. J. Appl. For. 1999, 16, 96-102.

46. Smith, C.C. The coevolution of pine squirrels (Tamiasciurus) and conifers. Ecol. Monogr. 1970, 40, 349-371. [CrossRef]

47. Gurnell, J. Squirrel numbers and the abundance of tree seeds. Mammal Rev. 1983, 13, 133-148. [CrossRef]

48. Stiell, W.M. Characteristics of eastern white pine and red pine. In Proceedings of the White and Red Pine Symposium, Chalk River, ON, Canada, 20-22 September 1977; Cameron, D.A., Ed.; Department of Environment, Canadian Forest Service: Sault Ste. Marie, ON, Canada, 1978.; pp. 7-51.

49. Kotar, J. Managing white pine: Finding the proper niche. In Proceedings of the White Pine Symposium: History, Ecology, Policy and Management, Duluth, MN, USA, 16-18 September 1992; Stine, R.A., Baughman, M.J., Eds.; Department of Forestry Resources, University of Minnesota: St. Paul, MN, USA, $1992 . ;$ pp. 150-156.

50. Pinto, F. Silvicultural practices in Ontario's white pine forests. In Proceedings of the White Pine Symposium: History, Ecology, Policy and Management, Duluth, MN, USA, 16-18 September 1992; Stine, R.A., Baughman, M.J., Eds.; Department of Forestry Resources, University of Minnesota: St. Paul, MN, USA, $1992 . ;$ pp. 170-178.

51. Ontario Ministry of Natural Resources (OMNR). A Silvicultural Guide for the Great Lakes-St Lawrence Conifer Forest in Ontario; Queens's Printer: Ottawa, ON, Canada, 1998.

52. Van Arsdel, E.P. Environment in relation to white pine blister rust infection. In Biology of Rust Resistance in Forest Trees: Proceedings of a NATO-IUFRO Advanced Study Institute, 17-24 August, 1969; Hoff, R.J., McDonald, G.I., Eds.; Misc. Pub. No. 1221; USDA Forest Service: Washington, DC, USA, 1969; pp. $479-493$.

53. French, D.W. White pine blister rust can be controlled. In Proceedings of the White Pine Symposium: History, Ecology, Policy and Management, Duluth, MN, USA, 16-18 September 1992; Stine, R.A., Baughman, M.J., Eds.; Department of Forestry Resources, University of Minnesota: St. Paul, MN, USA, 1992.; pp. 123-125.

54. White, M.A.; Brown, T.N.; Host, G.E. Landscape analysis of risk for white pine blister rust in the Mixed Forest Province of Minnesota, U.S.A. Can. J. For. Res. 2002, 32, 1639-1650. [CrossRef]

55. Coulombe, C.; Bélanger, G.; Lavallée, R.; Laflamme, G. A Simple Effective Tool for Controlling White Pine Weevil and Blister Rust on Norway Spruce and Eastern White Pine; Natural Resources Canada, Canadian Forest Service, Laurentian Forestry Centre: Sainte-Foy, QC, Canada, 2004.

56. Hodge, J.C.; Juzwik, J.; Gross, H.L.; Retnarkan, A. White Pine Blister Rust and White Pine Weevil Management: Guidelines for White Pine in Ontario; Ontario Ministry of Natural Resources: Ottawa, ON, Canada, 1989.

57. Logan, K.T. Growth of Tree Seedlings as Affected by Light Intensity. II. Red Pine, White Pine, Jack Pine and Eastern Larch; Tech. Note 121; Department of Forestry: Ottawa, ON, Canada, 1966.

58. Messier, C.; Parent, S.; Chengaou, M.; Beaulieu, J. Juvenile growth and crown morphological plasticity of eastern white pine (Pinus strobus L.) planted along a natural light gradient: Results after six years. For. Chron. 1999, 75, 275-279. [CrossRef]

59. Burgess, D.; Pinto, F.; Wetzel, S. Some Management Implications from an Eastern White Pine Regeneration Experiment; Technology Transfer Note 28; Forestry Research Applications Pacific Forestry Centre: Saanich, BC, Canada, 2002. 
60. Boucher, J.-F.; Bernier, P.Y.; Margolis, H.A.; Munson, A.D. Growth and physiological response of eastern white pine seedlings to partial cutting and site preparation. For. Ecol. Manag. 2007, 240, 151-164. [CrossRef]

61. Van Arsdel, E.P.; Riker, A.J.; Kouba, T.F.; Suomi, V.E.; Bryson, R.A. The Climatic Distribution of Blister Rust on White Pine in Wisconsin; Stn. Pap. 87; U.S. Department of Agriculture, Forest Service, Lake States Forest Experiment Station: St. Paul, MN, USA, 1961.

62. Robbins, K.; Jackson, W.A.; McRoberts, R.E. White pine blister rust in the eastern Upper Peninsula of Michigan. North. J. Appl. For. 1988, 5, 263-264.

63. Kayahara, G.J.; Armstrong, C.L. Understanding First Nations rights and perspectives on the use of herbicides in forestry: A case study from northeastern Ontario. For. Chron. 2015, 91, 126-140. [CrossRef]

64. Lancaster, K.F.; Leak, W.B. A Silvicultural Guide for White Pine in the Northeast; Gen. Tech. Rep. NE-41.; U.S. Department of Agriculture, Forest Service, Northeastern Forest Experiment Station: Broomall, PA, USA, 1978.

65. Heinselman, M.L. Fire in the virgin forests of the Boundary Waters Canoe Area, Minnesota. Quat. Res. 1973, 3, 329-382. [CrossRef]

66. Quinby, P.A. Self-replacement in old-growth white pine forests of Temagami, Ontario. For. Ecol. Manag. 1991, 41, 95-109. [CrossRef]

67. Stiell, W.M. Seeding and Planting Red Pine and White Pine; Tech. Note No. 80; Canada Department of Northern Affairs and National Resources, Forestry Branch Forest Research Division: Ottawa, ON, Canada, 1959.

68. Stiell, W.M.; Berry, A.B. Limiting white pine weevil attacks by side shade. For. Chron. 1985, 61, 5-9. [CrossRef]

69. Paquette, A.; Messier, C. The role of plantations in managing the world's forests in the Anthropocene. Front. Ecol. Environ. 2010, 8, 27-34. [CrossRef]

70. Engle, L.G. Releasing White Pine from Oak and Aspen; Tech. Note No. 346; USDA Forest Service, Lake States Forest Experiment Station: St. Paul, MN, USA, 1951.

71. Conklin, D.A.; Fairweather, M.L.; Ryerson, D.E.; Geils, B.W.; Vogler, D.R. White Pines, Blister Rust and Management in the Southwest; R3-FH-09-01; U.S. Department of Agriculture, Forest Service, Southwest Region: Albuquerque, NM, USA, 2009.

72. Stiell, W.M.; Robinson, C.F.; Burgess, D. 20-year growth of white pine following commercial improvement cut in pine mixedwoods. For. Chron. 1994, 70, 385-394. [CrossRef]

73. Pitt, D.G.; Meyer, T.; MacDonald, L.; Buscarini, T.; Thompson, D.G. Application of slow-release tablets to enhance white pine regeneration: Growth response and efficacy against white pine blister rust. Can. J. For. Res. 2006, 36, 684-698. [CrossRef]

74. Lavallée, A. The Spread of White Pine Blister Rust in Young White Pine Plantations; Info. Rep. LAU-X-101; Canadian Forestry Service, Laurentian Forestry Centre: Quebec City, QC, Canada, 1992.

75. Canadian Forest Service (CFS). White Pine Blister Rust: Knowledge, Control and Innovation; Canadian Forest Service, Laurentian Forestry Centre: Sainte-Foy, QC, Canada, 2012.

76. Laflamme, G.; Blais, R.; Desgagné, D. Control of Cronartium ribicola in Pinus strobus plantations. In Proceedings of the 1st IUFRO Rusts of Forest Trees Working Party Conference, Saariselkä, Finland, 2-7 August 1998; Jalkanen, R., Crane, P.E., Walla, J.A., Aalto, T., Eds.; Finnish Forest Research Institute: Helsinki, Finland, 1998.; pp. 299-303.

77. Krebs, C.; Boutin, S.; Boonstra, R.; Sinclair, A.; Smith, J.; Dale, M.; Turkington, R. Impact of food and predation on the snowshoe hare cycle. Science 1995, 269, 1112-1115. [CrossRef] [PubMed]

78. Asselin, H.; Basile, S. Éthique de la recherche avec les peuples autochtones: Qu'en pensent les principaux intéressés? Éthique Publique 2012, 14, 333-345. [CrossRef]

79. Roy, C.; Imbeau, L.; Mazerolle, M.J. Transformation of abandoned farm fields into coniferous plantations: Is there enough vegetation structure left to maintain winter habitat of snowshoe hares? Can. J. Zool. 2010, 88, 579-588. [CrossRef]

80. Germain, R. Évaluation de L'acceptabilité Sociale par la Communauté Algonquine de Pikogan d'une Stratégie D’amÉnagement écosystémique. Master's Thesis, Département des sciences appliquées, Université du Québec en Abitibi-Témiscamingue, Rouyn-Noranda, QC, Canada, 2012.

81. Deutsch, N.; Davidson-Hunt, I. Pikangikum family hunting areas and traplines: Customary lands and aboriginal landuse planning in Ontario's Far North. In Planning Co-Existence: Aboriginal Considerations and Approaches in Land Use Planning; Stevenson, M.G., Natcher, D.C., Eds.; Canadian Circumpolar Institute Press: Edmonton, AB, Canada, 2010; pp. 149-170. 
82. Asselin, H.; Larouche, M.; Kneeshaw, D. Assessing forest management scenarios on an Aboriginal territory through simulation modeling. For. Chron. 2015, 91, 426-435. [CrossRef]

83. Attiwill, P.M. The disturbance of forest ecosystems: The ecological basis for conservative management. For. Ecol. Manag. 1994, 63, 247-300. [CrossRef]

84. Bergeron, Y.; Harvey, B.; Leduc, A.; Gauthier, S. Forest management guidelines based on natural disturbance dynamics: Stand-and forest-level considerations. For. Chron. 1999, 75, 49-54. [CrossRef]

85. Drever, C.R.; Peterson, G.; Messier, C.; Bergeron, Y.; Flannigan, M. Can forest management based on natural disturbances maintain ecological resilience? Can. J. For. Res. 2006, 36, 2285-2299. [CrossRef]

86. Ribot, J.C.; Agrawal, A.; Larson, A.M. Recentralizing while decentralizing: How national governments reappropriate forest resources. World Dev. 2006, 34, 1864-1886. [CrossRef]

87. Garibaldi, A.; Turner, N. Cultural keystone species: Implications for ecological conservation and restoration. Ecol. Soc. 2004, 9. [CrossRef]

88. Higgs, E.S. What is good ecological restoration? Conserv. Biol. 1997, 11, 338-348. [CrossRef]

89. Stevenson, M.G.; Webb, J. Just another stakeholder? First Nations and sustainable forest. In Towards Sustainable Management of the Boreal Forest; Burton, P.J., Messier, C., Smith, D.W., Adamowicz, W.L., Eds.; NRC Research Press: Ottawa, ON, Canada, 2003; pp. 65-112.

(C) 2017 by the authors. Licensee MDPI, Basel, Switzerland. This article is an open access article distributed under the terms and conditions of the Creative Commons Attribution (CC BY) license (http://creativecommons.org/licenses/by/4.0/). 